\title{
EVALUATION WITH STREAM CHARACTERISTICS OF DOWNSTREAM FLOOD PROBLEMS AFTER DAM CONSTRUCTION
}

\author{
Tamer Bagatur, Nizamettin Hamidi \\ Civil Engineering Department, Engineering Faculty, Dicle University, 21280 Diyarbakir, Turkey
}

Submitted 18 Oct. 2012; accepted 03 Oct. 2013

\begin{abstract}
The flood may cause serious loss of life and property. The evaluation of flood events is necessary for the planning and design of engineering projects. In a dam, flood problems should be considered for both upstream and downstream conditions. The characteristics of flood problems can be derived from observation of dam sites. This paper aims to evaluate the impact of flood hazards from spillway based on downstream conditions after dam construction. Also, the paper discusses downstream flood problems depending on stream characteristics in an example dam site. In results, three reasons are determined for downstream floods problems: control problems of spillway gates, the naturally developing vegetation through channel flow line and incompetence of stream cross-section for carrying of flood flows. Therefore, downstream conditions should be investigated before dam construction. This investigation can be considered in the planning phase. In addition, the cross-section and longitudinal profile of stream should be controlled via maintenance of stream after dam construction. In stream cross-section problems (such as vegetation, incompetence and irregularities), some modifications (e.g. straighten, deepen, and widen) can be applied with engineering works.
\end{abstract}

Keywords: environmental impact assessment, flood damages, dam downstream condition, stream cross-section, environmental sustainability, environmental politics.

Reference to this paper should be made as follows: Bagatur, T.; Hamidi, N. 2014. Evaluation with stream characteristics of downstream flood problems after dam construction, Journal of Environmental Engineering and Landscape Management 22(02): 96-104. http://dx.doi.org/10.3846/16486897.2013.852555

\section{Introduction}

Flooding is the consequence of the lack of stream capacity to carry huge volumes of runoff induced by heavy precipitation or snow melt. Worldwide, floods are responsible for the fatalities and the economic losses. Therefore, people have fought to decrease the negative impacts of floods (Julien 2002). For example, Guzzetti et al. (2005) evaluated flood and landslide risk in Italy.

Water resources projects are very large national projects requiring huge dimensions. Hence, the planning and design of such systems must be performed with great care. The management and control of water resources requires the conception, planning, and execution of designs to use of the water or avoid damages from too much water. More alternatives must be considered in the planning phase.

There are around 40000 large dams (>15 m high) worldwide (Jackson et al. 2001). A dam is the most important structure in water resources projects. The dams are probably built for the purposes of irrigation, energy, flood control, and water supply. In almost all dams, provision must be made for the safe discharge of excess water by the construction of a spillway. A spillway is that component of a dam which serves to evacuate the flood wave from the reservoir without damaging the dam structure (Chow 1959). It may be controlled or uncontrolled (or gated) type. If flow cross-section of river and stream is insufficient, cross-section will not carry of dam discharges. Thus, downstream floods can be observed. These floods negatively impact environmental and agricultural purposes. All water resources projects (dam, irrigation channel, hydroelectric power plant, etc.) are planned for the future. But, downstream effects of dam projects are rarely considered in project appraisal. Therefore, the dam projects must be evaluated for both upstream and downstream flood conditions. Fitzhugh et al. (2011) investigated

Corresponding author: Tamer Bagatur

E-mail: tbagatur@dicle.edu.tr 
the impact of dams on flood flows in the United States. Downstream conditions must be investigated before dam construction for downstream flood risk. Also, the crosssection and longitudinal profile of stream must be controlled via maintenance of stream after dam construction. Because, maintenance and operation are important processes after the dam construction works. Non-uniform cross-sectional profiles, meanders, riffles and pools, and vegetation increase the heterogeneity of flow depths and velocities. The water depths and velocities are significant on stream channel hydraulics (Yen 2002).

The objective of this study is to evaluate causes and effects of downstream flood problems after dam construction. In addition, this paper recommends some technical approaches for protecting from downstream flood impacts. These approaches include stream channel geometry and roughness characteristics after dam construction. As an example dam site, this paper also describes some technical solutions for downstream flood problems on agriculture areas of the Goksu dam in Southeast of Turkey. The Goksu flood event is different from that presented in textbooks.

\section{Background}

\subsection{Dam planning}

Planning is an important step in the development of the water resources project. Project evaluation is developed based on economic, financial, environmental, and social considerations. Therefore, the planning and design of water resources projects must be performed with great care. The poor forecasts or estimates may lead to poor planning. Thus, the consequences of poor planning can be arrived large problems. In dam planning and design, both upstream and downstream conditions must be considered and investigated for negative impacts on flood-threatened lands with respect to environmental and agricultural purposes. These investigations should be aimed at predicting the structural problems.

\subsection{GIS technique for water resources}

In nowadays, computer simulation, analysis and its different applications (for example, GIS) are a popular way for evaluating of water resources projects. Geographic Information System (GIS) technology has been used to develop solutions for water resource engineering problems. The subjects of GIS can be summarized such as assessing water quality, determining water availability, preventing flooding, understanding the natural environment, managing water resources on a local or regional scale and mapping of river channel plan and bank erosion probability. Overton (2005) used GIS in modeling floodplain inundation on a regulated river. Shahapure et al. (2010) studied on flood simulation using GIS. In recent years, GIS has become an excellent tool for spatial date storage, visualization, and analysis. Thus, the downstream conditions of dam projects can be evaluated with GIS technique before and after dam construction.

\subsection{The human role in changing stream channels}

The extrinsic and intrinsic human roles affecting channels have been thought of as role in changing river channels. Direct consequences of human activities affect river channels through engineering works including canalization, dam construction, diversion and culvert. Gregory (2006) evaluated the human role in changing river channels in detail. There are many negative side effects of the dam construction on the downstream river's regime. Particularly, changing of river cross-section is most evident changes of size, shape and composition. Moreover, the overall channel plan form, the network and the ecology can be changed.

\subsection{Flood problem}

Various types of open channel problem such as flood occur in engineering practice. A flood is the result of runoff from rainfall and melting snow in quantities too great to be confined in the low-water channels of streams. Precipitation and stream flow vary widely from year to year. Flood problems involve a unique set of physical conditions and constraints, which can be resolved by the careful coordination the various disciplines. The physical facts of most flooding situations are against the planner who attempts to provide absolute flood control. Therefore, dam projects should be evaluated for floods depending on downstream conditions. The downstream conditions include checking of cross-section and longitudinal profile of stream. Therefore, the cross-section and longitudinal profile have a significant effect on downstream floods.

\subsection{Spillway and radial gates}

Operation of a storage reservoir is governed by the inflow. During normal periods of river flow, the reservoir will be maintained at the normal pool level for the operation of water supply purposes. If extremely high flows are can be drawn to such an elevation that the minimum expected flood flow will be sufficient to restore the active storage to its maximum level. A spillway is that component of a dam which serves to evacuate the flood wave from the reservoir without damaging the dam structure (Chow 1959; Chanson 2004). Shortly, a spillway is the safety valve for a dam. It may be controlled or uncontrolled. A controlled spillway is provided with crest gates. Gates permit the operator to control the release of water downstream for various purposes. The relation between storage and outflow for a reservoir with spillway is dependent on the number of gate. Storage in reservoir may modify the shape of a 
flood wave more markedly than an equivalent length of natural channel. The construction of a dam usually leads to control variations in reservoir water level depending on climatic conditions. Thus, downstream flood control may be made with reservoir storage and gradually-varied spillway releases.

\subsection{Stream cross-section and flow line}

Producing a cross-section of a river channel is fundamental to all river studies. A cross-section refers to the section of a channel taken transverse to the direction of the flow. Cross-section and longitudinal profile analysis to determine the best of several alternatives is required in planning most projects. The channel may consist of a main channel carrying normal discharges. The floodplain carries flow in excess of the channel capacity.

\subsection{Roughness of stream channel and vegetation}

In natural rivers and streams channel topography, bank vegetation, and in-stream woody debris may have a great influence on hydraulics. Vegetation is an important roughness element in channels. Reduced flow velocity around vegetation or woody debris leads to deposition of the fine sediment that is essential for bank cohesion. The accumulation of debris and excavation materials in the stream beds decreases the water carriage capacity of the bed and causes the floods. Hydraulically, debris act as large roughness elements that provide a varied flow environment, reduce average velocity, and locally elevate the water-surface profile. This can significantly increase flood travel time. Azami et al. (2004) examined the effects of a

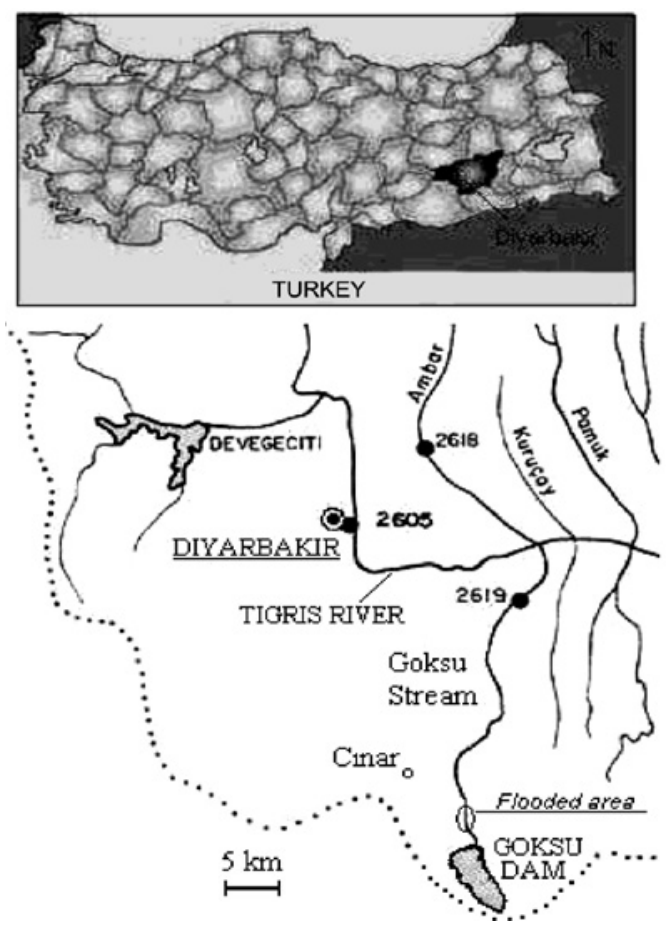

Fig. 1. Location map of study area dam reservoir flood control on riparian plant communities. Nikora et al. (2008) examined vegetation effects on hydraulic resistance in small streams. Also, they suggested simple quantitative relationships for predicting and quantifying these effects using the plant characteristics.

\subsection{Hydraulic analysis: water-surface profile and standard step method}

The hydraulic analysis of natural channels is similar to that of engineered channels. Hydraulic analysis of the flow in streams and rivers is performed using computer programs employing the varied flow equations. Computer programs, such as HEC-RAS (developed by the U. S. Army Crops of Engineers Hydrologic Engineering Center) and MIKE 11 (developed by DHI Water and Environment in Denmark), based on the preceding concepts are available for the computation of water-surface profiles. Water surface profiles can be examined standard step method. This method is easily adapted to prismatic channels with high precision. A reasonably accurate determination of the water-surface profile is possible by this method if the increments of depth are small. Billa et al. (2011) used as input into a MIKE 11 GIS and hydrological modeling process for flood inundation mapping of the Langat River Basin in Malaysia. Uniform flow rarely occurs in natural streams because of changes in depth, width, and slope along the channel. Therefore, the engineer is often concerned with non-uniform (varied) flow in open channels. One method of solving problems of non-uniform flow utilizes a stepby-step procedure.

\subsection{Environmental, economic and social impacts}

Analysis of the environmental and social impacts of the various project alternatives is important studies in dam construction. Large dams are often criticized because of their negative environmental and social impacts: changes in water and food security, increases in communicable diseases, and the social disruption caused by construction and involuntary resettlement. The impact of hydraulic engineering works and human activities on hydrology of stream basin has become a hot issue along with the economy and social development.

\section{Materials and methods}

\subsection{Study area and dam site description}

This study was conducted in the Goksu Stream Basin, which is located in the province of Diyarbakir $\left(37^{\circ} 41^{\prime} \mathrm{N}\right.$, $40^{\circ} 26^{\prime} \mathrm{E}$, in the southeastern Anatolia region of Turkey). This basin has a drainage area of $734 \mathrm{~km}^{2}$. Goksu stream is $33 \mathrm{~km}$ long, flows directly into the Tigris River. A diagram of the study field is shown in Figure 1. Also, Table 1 shows the main characteristics of study area and dam site. 
Table 1 . The main characteristics of study area

\begin{tabular}{ll}
\hline Basin name: & Dicle Basin \\
\hline Stream name: & Goksu Stream \\
Location: & Diyarbakir/Turkey \\
Drainage area & $734 \mathrm{~km}^{2}$ \\
Annual average rainfall & $487.6 \mathrm{~mm}$ \\
Dam name: & Goksu Dam \\
Construction year: & $1987-1991$ \\
Dam volume: & 1.632 million $\mathrm{m}^{3}$ \\
Dam height & $46 \mathrm{~m}$ \\
Dam crest elevation & $702 \mathrm{~m}$ \\
Irrigation Area: & $35.82 \mathrm{~km}^{2}$ \\
Reservoir volume at normal & $62 \mathrm{million}^{3}$ \\
water surface elevation: & \\
Reservoir area at normal water & $4 \mathrm{~km}^{2}$ \\
surface elevation: & \\
\hline
\end{tabular}

\subsection{Goksu dam and spillway structure}

Figure 2 illustrates cross-section of Goksu dam and spillway structure. The dam was built for irrigation purposes as earth-fill type. The length of dam crest and crest width is $673.50 \mathrm{~m}$ and $10.00 \mathrm{~m}$, respectively.

The spillway structure of dam is controlled with radial gates. The spillway has four radial gates (Fig. 3). The dimensions of radial gates are $7.50 \mathrm{~m}$ (horizontal) and $11.00 \mathrm{~m}$ (vertical). The length of spillway crest is $31.80 \mathrm{~m}$. Spillway design discharge $\left(Q_{10000}\right)$ is $2215 \mathrm{~m}^{3} \mathrm{~s}^{-1}$.

Radial gate flow is a type of variable-area orifice flow, which may be either free or submerged. The general equation for spillway flow through an undershot gate can be derived from the Bernoulli equation and expressed as:

$$
Q_{\text {gate }}=C_{d} \cdot w \cdot B \cdot \sqrt{2 g H},
$$

where: $Q_{\text {gate }}=$ discharge (spillway gate flow); $C_{d}=$ coefficient of discharge, typically $0.5-0.7 ; \mathrm{w}=$ vertical opening of gate; $\mathrm{B}=$ gate width; $\mathrm{g}=$ gravitational constant; and $H=$ a head term.

The relation between storage and outflow for a reservoir with spillway gates is dependent on the number of gate. For four radial gates of Goksu dam, spillway total discharge $\left(Q_{s p}\right)$ can be calculated as:

$$
Q_{s p}=Q_{\text {gate1 }}+Q_{\text {gate2 }}+Q_{\text {gate3 }}+Q_{\text {gate4 }} .
$$

\subsection{Characteristics of Goksu streamflow records}

Values of discharge are necessary for determination of streamflow characteristics. Also, they are part of the information routinely collected at streamflow gaging stations. Discharge data may be either instantaneous values or may be mean values. These valuables can be obtained by averaging flows through specified increments of time such as daily, monthly, annually, or for all or part of the period of record. Observation period of stream flow characteristics is from 1960 to 1987 . In these years, Figure 4 shows variation of maximum discharges for 28 water years at the downstream gage. Maximum discharges are observed from 10 to $60 \mathrm{~m}^{3} \mathrm{~s}^{-1}$. Mean annual maximum discharge is estimated $19 \mathrm{~m}^{3} \mathrm{~s}^{-1}$.

Figure 5 illustrates the long-term mean monthly discharges for 20 years. The long-term mean annual discharge of stream was $2.86 \mathrm{~m}^{3} \mathrm{~s}^{-1}$ before dam construction.
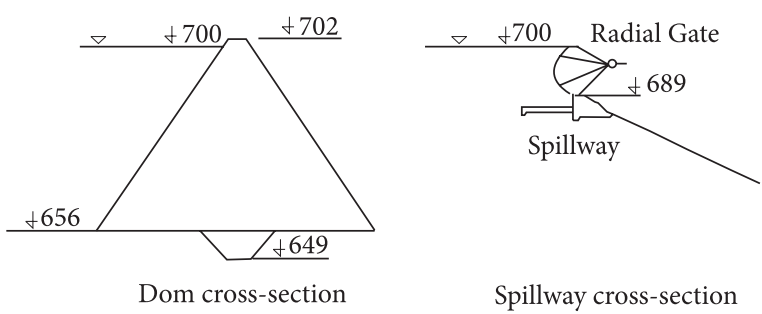

Fig. 2. Goksu dam and gated spillway structure

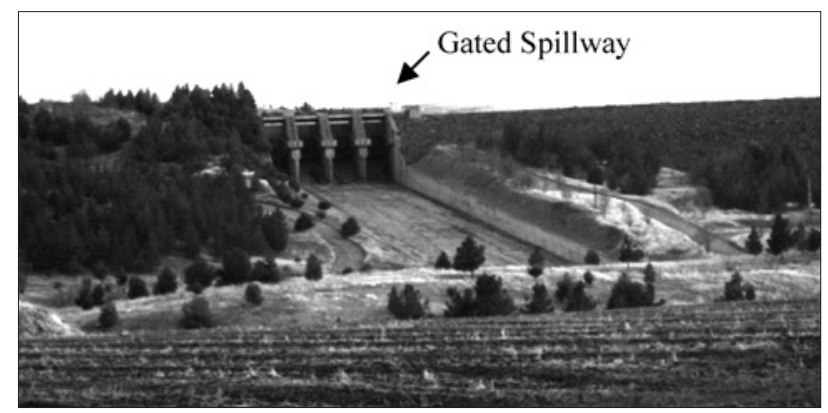

Fig. 3. Gated spillway structure of Goksu dam

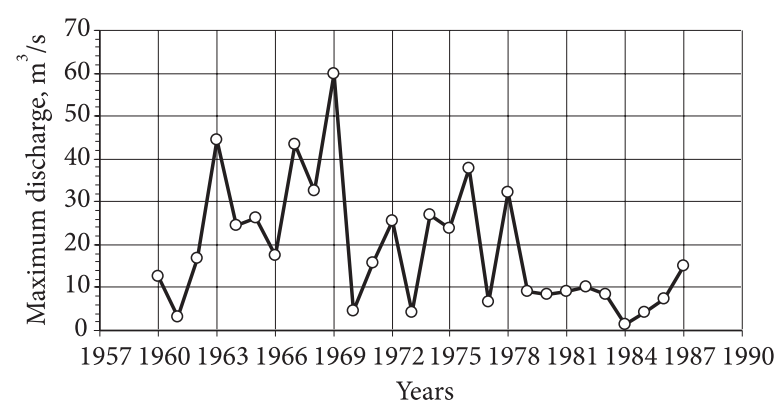

Fig. 4. Variation of maximum flow values of Goksu stream in different years (dam construction was started in 1987 and completed in 1995)

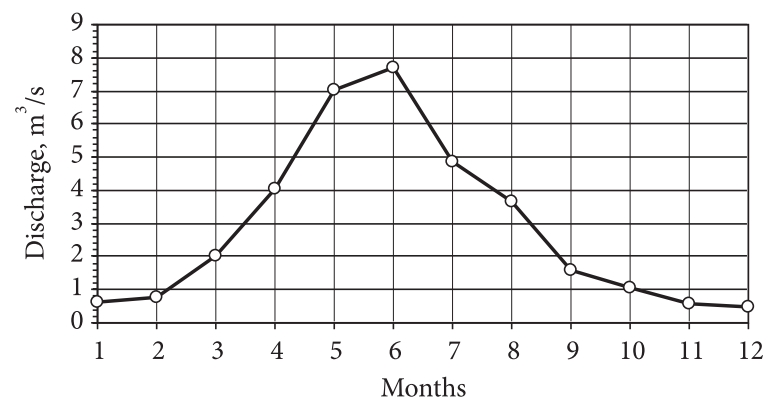

Fig. 5. Long-term mean monthly discharge of Goksu stream (observation period is from 1968 to1987) 


\section{4. "Zero" cross-section and changes in stream channel line}

Rivers and stream carry material in the form of solid particles. These particles may alternatively be deposited on the river bed (sedimentation) and entrained into the moving water (erosion). Although design engineers are aware of the extreme hydrology of the catchments, it appears that they ignore the catchments erosion and sediment-load motion taking place during extreme floods. Thus, cross-section and flow line of the stream change with sedimentation and erosion in time. Moreover, channel cross-sections can not carry flood capacity of the stream in flood time. For downstream flood management, the cross-section and longitudinal profile of stream are the most important scientific knowledge. In Goksu basin, the stream cross-sections and flow line were surveyed after 2004 flood. Some cross-sections of stream are filled with bed material. The cross-section of the stream is nearly flat in flooded areas. Thus, "zero" cross-section is observed. The channel of Goksu stream has undergone significant hydrologic and morphologic changes in the relatively short period. For evaluating the effects of vegetation, riverbank erosion and stability on flood, the bed and bank material is important for the resulting depth and width. The channel of Goksu stream is entirely alluvial in composition with banks of sand and clay and a bed of fine to medium gravel with dense vegetation. The predominant geomorphic process is over bank flooding and deposition.

\subsection{Roughness of stream channel}

In natural rivers and streams, channel topography, bank vegetation, and in-stream woody debris may have a great influence on hydraulics and physical habitat. Particularly, the naturally developing vegetation has a higher hydraulic roughness. Therefore, depth-discharge relationships should be established for the varying roughness conditions.

The Manning formula is used to estimate flow in open channel situations (Chow 1959). The Manning formula states:

$$
V=\frac{1}{n} \cdot R^{2 / 3} \cdot S^{1 / 2}
$$

where: $V$ is the cross-sectional average velocity $(\mathrm{m} / \mathrm{s}) ; n$ is the Manning coefficient; $R$ is the hydraulic radius ( $\mathrm{m})$; $S$ is the slope of the water surface or the linear hydraulic head loss.

The influence of roughness has been cataloged in the form of a roughness coefficient based on data obtained from field and laboratory observations. Typical values of the roughness coefficient, commonly called Manning coefficient $(n)$, are presented in Table 2 (Chow 1959).

The values of Manning coefficient $(n)$ include the effect of all hydraulic factors. For example, they include channel blockage by excessive aquatic vegetation.
In Goksu stream, the most striking visual change was from a sparse growth of streamside grasses to a dense growth of riparian woody vegetation. In such areas covered by dense vegetation, the vegetation characteristics play an important role on the magnitude of flow parameters such as velocities and depths.

Table 2. Variation with bed profile, vegetation and material type of Manning roughness coefficient in natural river channels

\begin{tabular}{llcc}
\hline \multirow{2}{*}{ Bed profile } & \multirow{2}{*}{$\begin{array}{c}\text { Vege- } \\
\text { tation }\end{array}$} & $\begin{array}{c}\text { Sand and } \\
\text { gravel }\end{array}$ & $\begin{array}{c}\text { Coarse } \\
\text { gravel }\end{array}$ \\
\hline Uniform & None & 0.020 & 0.030 \\
Uniform & Some & 0.040 & 0.050 \\
Undulating & None & 0.030 & 0.040 \\
Undulating & Some & 0.050 & 0.060 \\
Highly irregular & None & 0.055 & 0.070 \\
Highly irregular & Extensive & 0.080 & 0.090 \\
\hline
\end{tabular}

The behavior of grass in an open channel lining is complicated by the fact that grass stems bend as flow depth and shear stress increase. Vegetation will grow among the stones, after sediment has had an opportunity to be deposited between the stones. The aquatic vegetation growth resulted in a large increase in the roughness coefficient. According to Table 2, Manning coefficient ( $n$ ) can be determined as $0.060-0.080$ for Goksu stream due to dense vegetation and irregular bed profile.

\section{Results and discussion}

\subsection{Downstream floods}

In Goksu dam, the flood events have not observed from 1987 to 2003. In the time of flood of 2004, reservoir water was released from spillway gates due to enhancing of water elevation in reservoir. Thus, agricultural areas are flooded with released water. However, floods in some parts of the basin have lead to investigate of downstream conditions such as erosion, sedimentation, the stream line and crosssections. The cross-sections were investigated the probability of the flood storage capacity between $0-33 \mathrm{~km}$. As a result, from the spillway toe to $33^{\text {th }} \mathrm{km}$ of Goksu stream, it has been found to be more sensitive to a probable inundation. Inundation of agriculture areas supports the findings obtained by the study. Figure 6 shows stream channel banks covered by dense vegetation in flooded areas. The water depth increases due to stream channel banks covered by dense vegetation. Figure 7 shows stream channel configuration after dam construction and flood areas. Observations from agricultural areas close to the stream embankments mentioned flood depths of 1 to $2 \mathrm{~m}$ over land. Agriculture areas (62 hectares) suffered badly from flood conditions. Approximately $95 \%$ of the Goksu catchment is agricultural land, $65 \%$ of which is cultivated for arable crops. 


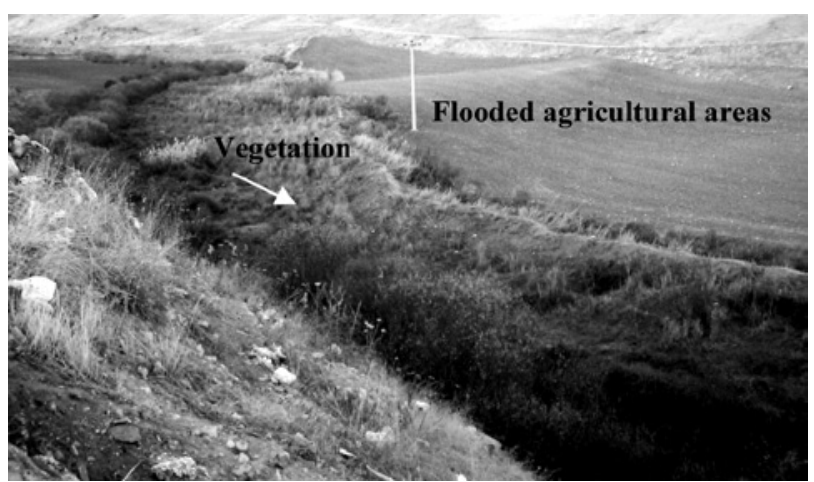

Fig. 6. Goksu channel banks covered by dense vegetation

\subsection{Spillway releases and reservoir water level}

In dam structures, the flood water is discharged through a radial gated spillway. Radial gates allow controlled discharges from reservoir. In this study, the field data were collected in February-March 2004. In these months, radial gates of Goksu dam were opened due to flood water. Figure 8 shows variation of total discharge $\left(\mathrm{Q}_{\mathrm{sp}}\right)$ versus time of released water from spillway gates in February 2004 flood. The spillway released flood water from 5 to $30 \mathrm{~m}^{3} \mathrm{~s}^{-1}$ within 25 days in February 2004 flood.

The 2004 flood event extended from February 5 to March 23, a period of 48 days. Figure 9 shows release discharges from spillway gates in March 2004 flood. The spillway gates were opened for release water flood from 22 to $8 \mathrm{~m}^{3} \mathrm{~s}^{-1}$ discharge within 23 days in March 2004 flood. Water elevation in reservoir is shown depending on days in Figure 10. On 5 February 2004, reservoir water level increased with flood time. Also, reservoir water level increased with flood time on 24 February 2004. Figure 11 shows Variation between reservoir water elevation and days in March 2004 flood. The reservoir water elevation was arranged for stable conditions with controlled spillway releases.

\subsection{Some considerations for safety of downstream floods}

Flood analysis studies are the multidisciplinary research field. The flood risk maps should be produced. Flood risk analysis and management can significantly contribute to safety and life living in flood areas at along streams and rivers.

The commonly accepted measures for reducing flood damage are as follows: a) Reduction of peak flow by reservoirs; b) Confinement of the flow within a predetermined channel by levees, flood walls, or a closed conduit; c) Reduction of peak stage by increased velocities resulting from channel improvement; d) Diversion of flood waters through a flood bypass, which may return the water to the same channel at a point downstream or deliver it to another channel or different watershed; e) Reduction of flood runoff by land management; $f$ ) Temporary evacuation of

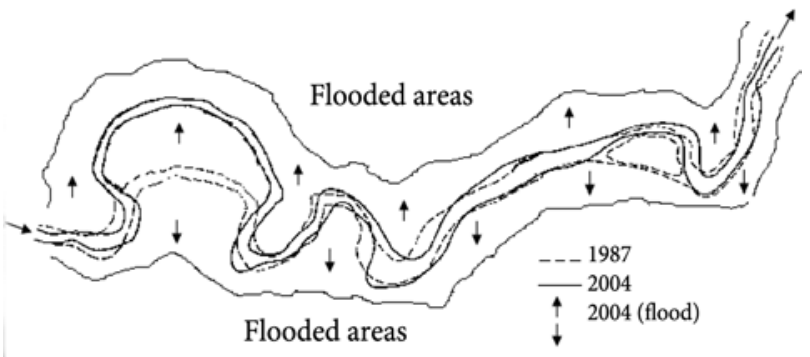

Fig. 7. Stream channel configuration after dam construction and flood areas (canal configuration in 1987 (dashed line) and 2004 (solid line) of Goksu stream)

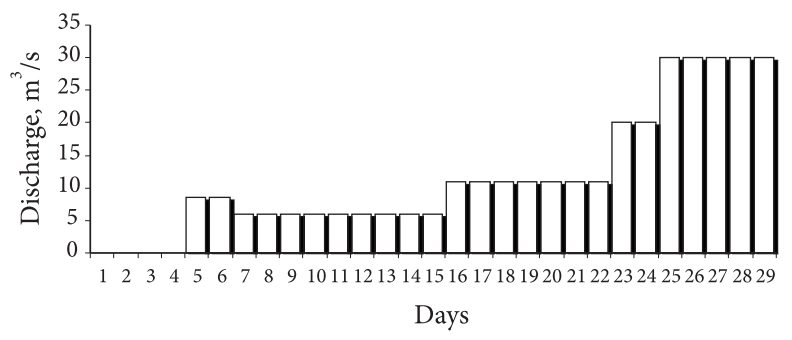

Fig. 8. Release discharges from gates of Goksu dam in the time of flood (February 2004)

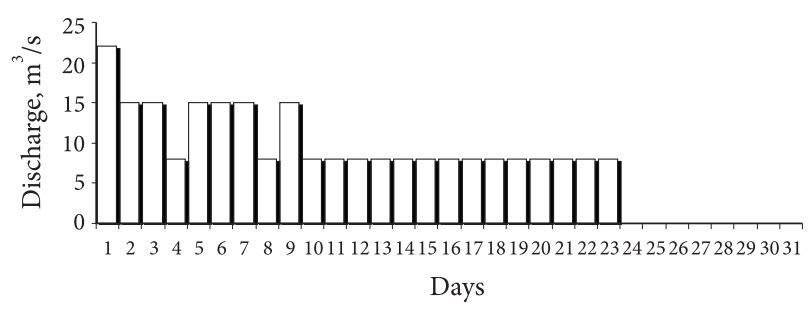

Fig. 9. Release discharges from gates of Goksu dam in the time of flood (March 2004)

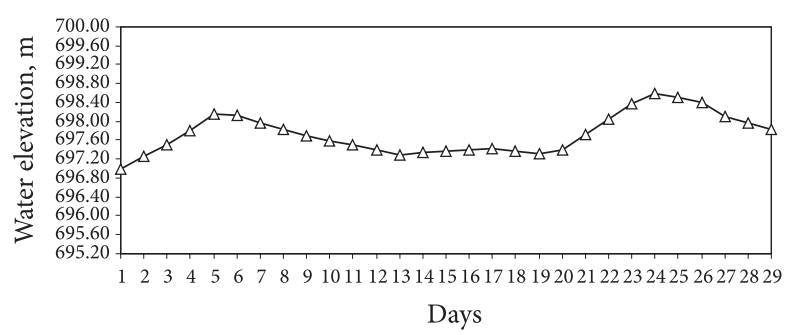

Fig. 10. Variation between reservoir water elevation and days in Goksu dam (February 2004)

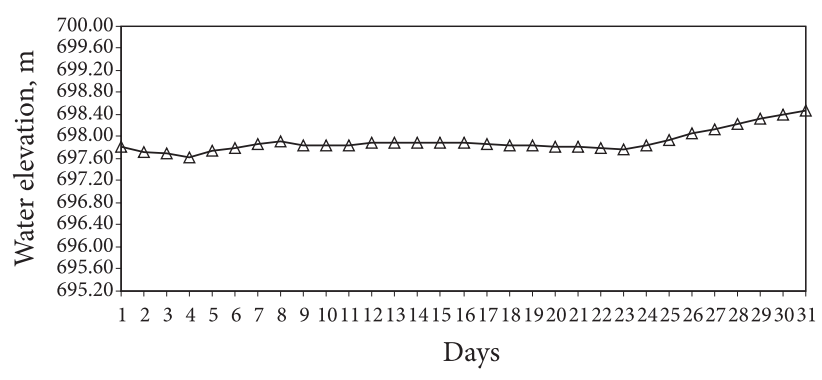

Fig. 11. Variation between reservoir water elevation and days in Goksu dam (March 2004) 
flood threatened areas on the basis of flood warnings; g) Flood plain management.

Some technical considerations can be suggested for safety of downstream floods as:

- Use of intensive structural technologies such as reshaping of the land surface.

- Deepening and widening the original cross-section is highly effective in increasing the flood carrying capacity of rivers.

- Water surface profile should be calculated before dam construction. For this, standard step method can be used.

These technical considerations present special requirements for evaluating flood damage reduction.

\subsection{Engineering works for solution of downstream flood problem}

Learning from practical cases is an essential factor in engineering design. Engineering practice is often a combination of theory and practical constraints. Downstream flood problems can be solved by the careful coordination based on past experience and analysis. In flood management, both structural measures and more economic nonstructural safety measures should be used. Flood-mitigation works often utilize a combination of measures such as the cross-section and longitudinal profile of stream. Natural channels may be improved for flood by regulating the flow in storage reservoirs, dredging, contraction works, bank stabilization, straightening, and snag removal. Also, the stream is straightened and deepened for flood capacity.

During the regulation process of the channels of rivers and streams, their natural bends were eliminated. Thus, the cross-sectional profile was formed artificially. Rivers regulated in such a way became comparatively straight channels arranged in the valley of a former meandering stream (Baublys 2006).

The local hydraulic conditions are determined by flow resistance and geometry of the channel. Engineering works aim to reconstruct longitudinal changes in hydraulic geometry and flow processes during the passage of flood.

Flood capacity can be increased by enlarging the cross section and straightening the alignment, smoothing

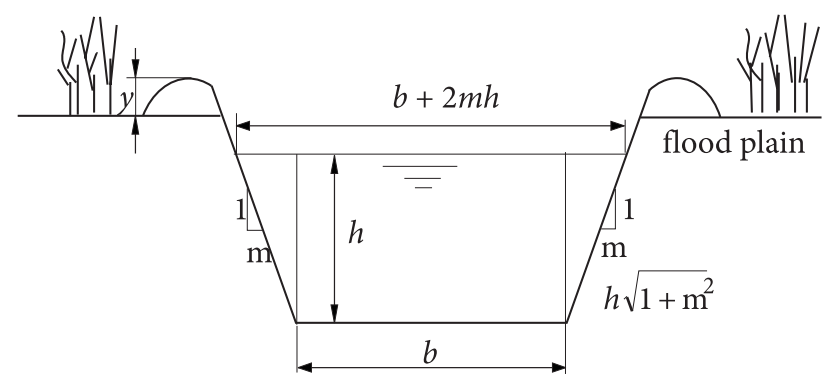

Fig. 12. New cross-section in Goksu dowstream the banks to reduce the value of Manning's coefficient $(n)$, and through the use of levees. Engineering works on streams and rivers serve a number of purposes: increasing the flow capacity, stabilizing the alignment, deepening the channel for navigation, and preventing bank erosion and sloughing.

Deepening and widening of the original cross-section is highly effective in increasing of the flood carrying capacity. In Goksu stream, flood capacity was increased by enlarging of the cross section and straightening of flow direction. Thus, the configuration of streams and rivers can be modified by dredging. These works are mainly to assure the safety of persons who are downstream of the dam.

\subsection{Modification and new channel design: trapezoidal channel cross-section}

Floods in some parts of the basin have lead to investigate and revise the cross-sections. Cross-section analysis is used to determine the conveyance and storage of a stream channel and over bank areas. In results of spillway releases, cross-section investigation and observation of flooded areas, it was be noticed that the original cross-section of stream had the conveyance problem due to dense vegetation, sedimentation and erosion. Therefore, new crosssection is considered deepening and widening of the original cross-section as stream modification. The main purpose of channel rehabilitation in the Goksu stream is for flood control. Thus, the new cross-section will serve as the main corridor for the flood flow.

The stream channel is $33 \mathrm{~km}$ long and has a surface width (top width) range of one to five meters. The gradient through the study reach is 0.0014 . Required new cross-sections are typically designed as trapezoidal section (Fig. 12). Stream section requirements are defined by the hydraulic calculation.

Wet area of trapezoidal cross-section (A):

$$
A=\left(b h+m h^{2}\right)
$$

where: $A$ is cross-sectional area $\left(\mathrm{m}^{2}\right) ; b$ is channel width; $h$ is flow depth; $m$ is bank slope.

Wet perimeter of trapezoidal cross-section $(P)$ :

$$
P=\left(b+2 h \sqrt{1+m^{2}}\right)
$$

Hydraulic radius $(R)$ :

$$
R=\frac{\left(b h+m h^{2}\right)}{\left(b+2 h \sqrt{1+m^{2}}\right)} .
$$

The new channel cross-section may be able to minimize damage to crops and property within the flood plain of the stream. Cross-section parameters must be obtained at sufficient intervals to define the flow carrying capacity of the stream. The value of river bed width $(b)$ is calculated according to the analysis and routing of flood flows. 
The design channel width $(b)$ refers to channel width in the straight reach between two bends corresponding to the design discharge $(Q)$. The design channel width $(b)$ may be determined by calculation from equations. From continuity and Manning equation:

$$
Q=A \cdot V=A \cdot\left(\frac{1}{n} R^{2 / 3} S^{1 / 2}\right),
$$

where: $Q$ is discharge of channel $\left(\mathrm{m}^{3} \mathrm{~s}^{-1}\right) ; A$ is cross-sectional area $\left(\mathrm{m}^{2}\right) ; V$ is the cross-sectional average velocity $\left(\mathrm{ms}^{-1}\right) ; n$ is the Manning coefficient; $R$ is the hydraulic radius (m); $S$ is the slope of the water surface or the linear hydraulic head loss.

Table 3 shows typical values of Manning roughness coefficient for man-made channel. The Manning coefficient $(n)$ of new channel cross-section was selected as 0.030 according to Table 3.

Table 3. Typical values of Manning roughness coefficient in forman-made channel (Chow 1959)

\begin{tabular}{clc}
\hline Number & \multicolumn{1}{c}{ Channel material } & $n$ \\
\hline 1 & Smooth earth & 0.018 \\
2 & Firm gravel & 0.023 \\
3 & Natural channels in good condition & 0.025 \\
& Natural channels with stones and & 0.035 \\
4 & weeds & 0.060 \\
5 & Very poor natural channels & 0.025 \\
6 & Gravel beds, straight & 0.040 \\
7 & Gravel beds plus large boulders & 0.026 \\
8 & Earth, straight, with some grass & 0.030 \\
$9 *$ & Earth, winding, no vegetation & 0.050 \\
10 & Earth, winding with vegetation
\end{tabular}

* selected value in present study.

After construction of Goksu dam, the average channel capacity has reduced due to stream ecology, habitat and the physical characteristics. The bed alternates in elevation through a series of pools and riffles. Also, the river bed generally composed of sand having a median size of $2 \mathrm{~mm}$. The discharge capacity has been enhanced by a new channel design. The design discharge of the trapezoidal cross-section is selected according to mean annual maximum discharge of the Goksu stream (estimated $19 \mathrm{~m}^{3} \mathrm{~s}^{-1}$ ).

The hydraulic characteristics of trapezoidal the crosssection are calculated with Equations (3), (4), (5), (6) and (7). Table 4 summarizes the hydraulic characteristics of the trapezoidal cross-section.

The new channel is about $10 \mathrm{~m}$ wide at the top, and this is the width of the flow at bankful stage. The bottom width of a trapezoidal channel having side slopes of 1 vertical on 1.5 horizontal is $4 \mathrm{~m}$. The depth of water is designed about $2 \mathrm{~m}$.

As a part of the modification project (study) reach $(29 \mathrm{~km})$ was excavated to replace the straightened channel in 2005 by DSI (Local State Hydraulic Work of Turkey). Figure 13 and Figure 14 show the new cross-section and flow line modification after engineering works.

Table 5 shows the characteristics of engineering works as a part of the modification project.

Table 4. The hydraulic characteristics of the new trapezoidal cross-section in the Goksu downstream

\begin{tabular}{lc}
\hline \multicolumn{1}{c}{ Parameter } & Value \\
\hline Discharge, $Q\left(\mathrm{~m}^{3} \mathrm{~s}^{-1}\right)$ & 19 \\
Manning coefficient, $n$ & 0.030 \\
Bank slope, $\mathrm{m}$ & 1.5 \\
Stream slope, $S$ & 0.0014 \\
Flow depth, $h(\mathrm{~m})$ & 2 \\
Width, $b(\mathrm{~m})$ & 4 \\
Area, $A\left(\mathrm{~m}^{2}\right)$ & 14 \\
Perimeter, $P(\mathrm{~m})$ & 12.94 \\
Hydraulic Radius, $R(\mathrm{~m})$ & 1.08 \\
Velocity, $V\left(\mathrm{~ms}^{-1}\right)$ & 1.31 \\
Floodplain height, $y(\mathrm{~m})$ & 1.5 \\
\hline
\end{tabular}

Table 5. Characteristics of engineering works

\begin{tabular}{ll}
\hline \multicolumn{1}{c}{ Description } & \multicolumn{1}{c}{ Value } \\
\hline Stream channel length & $33 \mathrm{~km}$ \\
Modified channel length & $29 \mathrm{~km}$ \\
Estimated work distance in day & $250 \mathrm{~m} /$ day $^{-1}$ \\
Finishing time of engineering works & $\frac{29000 \mathrm{~m}}{250 \mathrm{~m} / \text { day }}=116$ day \\
Excavated volume in the stream line & $300000 \mathrm{~m}^{3}$ \\
\hline
\end{tabular}

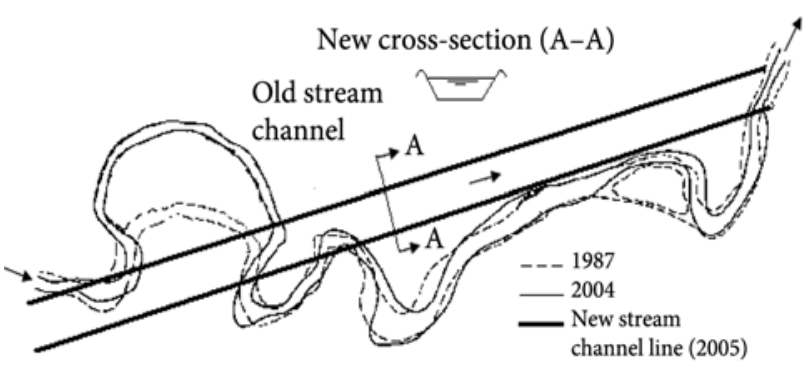

Fig. 13. Cross-section and flow line modification after flood event in Goksu dowstream

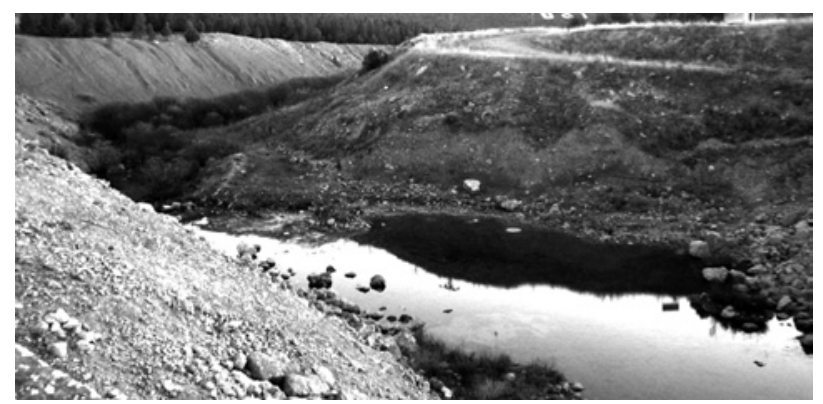

Fig. 14. View of new trapezoidal cross-section in Goksu downstream (November 2011) 


\section{Conclusions}

The evaluation of flood events is necessary of the planning and design of dam projects. The flood problems should be considered for both upstream and downstream conditions in dam. The characteristics of these problems can be derived from observation and investigation of dam sites.

In results, three reasons are determined for downstream floods problems in dam: control problems of spillway gates, the naturally developing vegetation through channel flow line and incompetence of stream cross-section for carrying of flood flows.

For downstream flood management, the crosssection and longitudinal profile of stream are the most important scientific knowledge. Therefore, downstream conditions should be investigated before dam construction. In addition, the cross-section and longitudinal profile of stream must be controlled via maintenance of stream after dam construction. In incompetence of cross-section geometry and longitudinal profile, some modifications (e.g. straighten, deepen and widen) can be applied. Thus, the stream is straightened and deepened for flood capacity.

Also, different safety margins may be derived considering the local conditions. Hence, environmental management is enhanced with defending of environmental and agricultural fields from spillway floods.

The case study showed that both flow resistance and cross-section geometry are vital factors to determine local hydraulics. The present investigation may assist engineering works associated with the planning, project, operation and maintenance of the dam site.

\section{Acknowledgment}

The authors would like to thank the DSI (Local State Hydraulic Works) for their assistance in providing data for this study.

\section{References}

Azami, K.; Suzuki, H.; Toki, S. 2004. Changes in riparian vegetation communities below a large dam in a monsoonal region: Fatuse Dam, Japan, River Research Applications 20(5): 549-563. http://dx.doi.org/10.1002/rra.763
Baublys, R. 2006. Investigation of deformation processes in channels of regulated streams, Journal of Environmental Engineering and Landscape Managemen 14(3): 141-148.

Billa, L.; Mansor, S.; Mahmud, A. R. 2011. Pre-flood inundation mapping for flood early warning, Journal of Flood Risk Management 4(4): 318-327.

http://dx.doi.org/10.1111/j.1753-318X.2011.01115.x

Chanson, H. 2004. The hydraulics of open channel flow. Oxford, UK: Butterworth-Heinemann. 650 p.

Chow, V. T. 1959. Open channel hydraulics. New York: McGrawHill. 680 p.

Fitzhugh, T. W.; Vogel, R. M. 2011. The impact of dams on flood flows in the United States, River Research. Applications 27(10): 1192-1215. http://dx.doi.org/10.1002/rra.1417

Gregory, K. J. 2006. The human role in changing river channels, Geomorphology 79(3-4): 172-191. http://dx.doi.org/10.1016/j.geomorph.2006.06.018

Guzzetti, F.; Stark, C. P.; Salvati, P. 2005. Evaluation of flood and landslide risk to the population of Italy, Environmental Management 36(1): 15-36. http://dx.doi.org/10.1007/s00267-003-0257-1

Julien, P. Y. 2002. River mechanics. Cambridge, UK: Cambridge University Press. $434 \mathrm{p}$. http://dx.doi.org/10.1017/CBO9781139164016

Jackson, R. B.; Carpenter, S. R.; Dahm, C. N.; McKnight, D. M.; Naiman, R. J.; Postel, S. L.; Running, S. W. 2001. Water in a changing world, Ecological Applications 11: 1027-1045. http://dx.doi.org/10.1890/1051-0761(2001)011[1027:WIAC $\mathrm{W}] 2.0 . \mathrm{CO} ; 2$

Nikora, V.; Larned, S.; Nikora, N.; Debnath, K.; Cooper, G.; Reid, M. 2008. Hydraulic resistance due to aquatic vegetation in small streams: field study, Journal of Hydraulic Engineering 134(9): 1326-1332. http://dx.doi.org/10.1061/(ASCE)07339429(2008)134:9(1326)

Overton, I. C. 2005. Modelling floodplain inundation on a regulated river: integrating GIS, remote sensing and hydrological models, River Research Applications 21(9): 991-1001. http://dx.doi.org/10.1002/rra.867

Shahapure, S. S.; Eldho, T. I.; Rao, E. P. 2010. Coastal urban flood simulation using FEM, GIS and remote sensing, Water Resorces Management 24(13): 3615-3640. http://dx.doi.org/10.1007/s11269-010-9623-y

Yen, B. C. 2002. Open channel flow resistance, Journal of Hydraulic Engineering 128(1): 20-39.

http://dx.doi.org/10.1061/(ASCE)0733-9429(2002)128:1(20)

Tamer BAGATUR. Dr Habil., Associate Prof., Department of Civil Engineering, Dicle University. Doctor Habil. of Science (Civil Engineering), Dicle University, 2009; Doctor of Science (Civil Engineering), Firat University, 2000. Employment: Associate Professor (2009), Senior Research Worker (2000), Junior Research Worker (1993), Engineer (1990). Publications: over 36 research paper. Research interests: fluid mechanics, river flows and process, interaction between hydraulic structures and the environment.

Nizamettin HAMIDI. Dr Habil., Assistant Prof., Department of Civil Engineering, Dicle University. Doctor Habil. of Science (Civil Engineering), Dicle University, 1995; Doctor of Science (Civil Engineering), Istanbul Technical University, 1994. Employment: Assistant Professor (1995), Senior Research Worker (1994), Junior Research Worker (1984), Engineer (1982). Publications: over 30 research paper. Research interests: hydraulic, hydrology, fluid mechanics, river flows and process, interaction between hydraulic structures and the environment. 